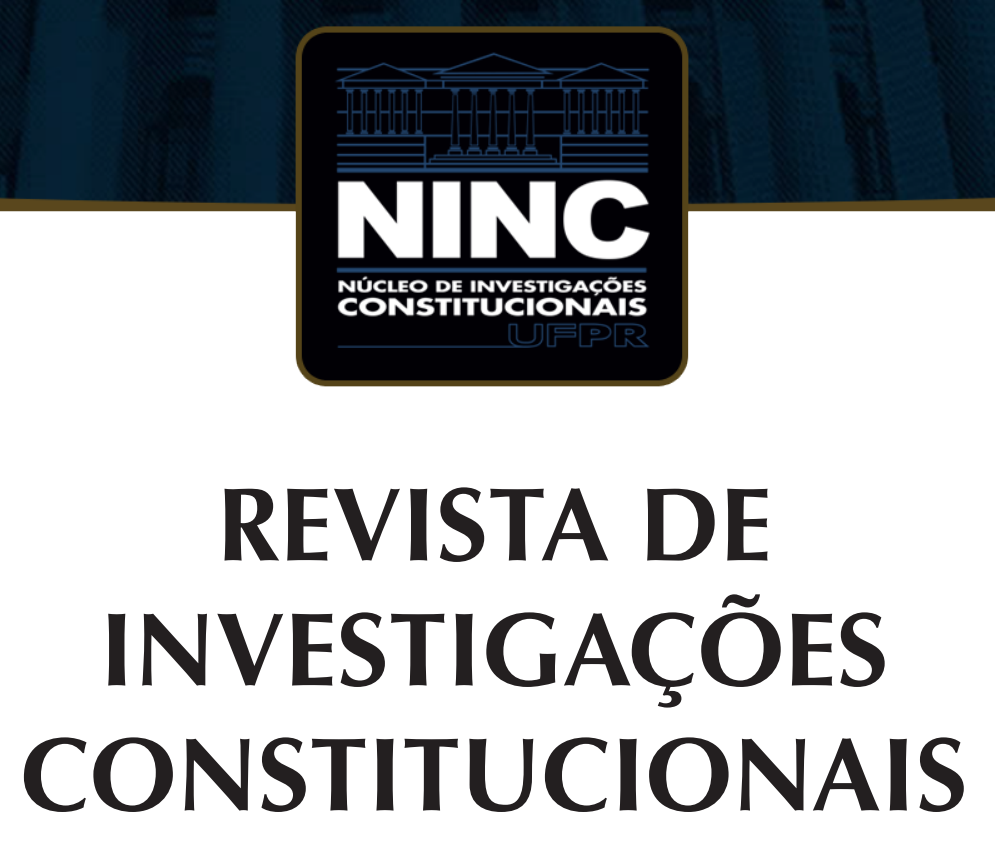

JOURNAL OF CONSTITUTIONAL RESEARCH

vol. 6 | n. 2 | maio/agosto 2019 | ISSN 2359-5639 | Periodicidade quadrimestral Curitiba | Núcleo de Investigações Constitucionais da UFPR | www.ninc.com.br 


\title{
Constitutional neutrality: an essay on the essential meaning of freedom of speech
}

\author{
Neutralidade constitucional: um ensaio sobre o \\ significado essencial da liberdade de expressão
}

\section{JOÃO DOS PASSOS MARTINS NETO ${ }^{1, *}$}

'Universidade Federal de Santa Catarina (Brasil) passos@pge.sc.gov.br https://orcid.org/0000-0002-1168-3201

Recebido/Received: $22.10 .2018 /$ October $22^{\text {th }}, 2018$ Aprovado/Approved: 17.11 .2019 / November 17 th 2019

\section{Abstract}

The present essay explores the essential meaning of freedom of speech in the context of contemporary constitutional democracy. In addressing the question of how free speech constitutional clause should be understood in an universe full of controversial cases, the study articulates three main propositions: 1.Freedom of speech is the right not to be prevented from speaking or not to be punished for speaking based on the alleged unacceptability of an idea (taken as incorrect, inappropriate, stupid, irrelevant, shocking, dangerous, etc.); 2 . Freedom of speech grants protection no matter the content of the message because the exchange of ideas is valuable for reasons other than the substantive qualities of what is said; to be worthy of protection, speech does not need to be infallible, clever or polite, but only play an expressive role in the process of discussion; 3. Freedom of speech doesn't collide with rights of others, especially in the case

\section{Resumo}

O presente ensaio explora o significado essencial da liberdade de expressão no contexto da democracia constitucional contemporânea. Ao abordar a questão de como a cláusula constitucional da livre expressão deve ser entendida em um universorepleto de casos controversos, o estudo apresenta três proposições principais: 1. A liberdade de expressão é o direito de não ser impedido de falar ou de não ser punido por falar com base na suposta inaceitabilidade de uma ideia (tomada como incorreta, inapropriada, estúpida, irrelevante, chocante, perigosa, etc.); 2. A liberdade de expressão garante proteção qualquer que seja o conteúdo da mensagem porque a troca de idéias é valiosa por outras razões que não as qualidades substantivas do que é dito; para ser digno de proteção, o discurso não precisa ser infalivel, inteligente ou polido, mas apenas desempenhar uma função expressiva no processo de discussão; 3. A liberdade de expressão não colide com direitos dos outros, especialmente

Como citar esse artigo/How to cite this article: MARTINS NETO, João dos Passos. Constitutional neutrality: an essay on the essential meaning of freedom of speech. Revista de Investigações Constitucionais, Curitiba, vol. 6, n. 2, p. 239-265, maio/ago. 2019. DOI: $10.5380 /$ rinc.v6i2.62470.

"Professor at the Federal University of Santa Catarina (Florianópolis-SC, Brazil). Master's in law and Doctor of Law from the Federal University of Santa Catarina. Visiting Scholar at the Columbia University in 2007-2008 (New York, NY, United States of America). Visiting Scholar at the UC Berkeley in 2018 (Berkeley, CA, United States of America). State Attorney at the Attorney General's Office of the State of Santa Catarina (Florianópolis-SC, Brazil).E-mail: passos@pge.sc.gov.br. 
of assertive speech acts, that is, assertions of facts and values that the speaker sincerely believes to be true or correct; even when the content sounds outrageous, asserting something doesn't imply violation of anyone's right, but rather it means the exercise of one's own right.

Keywords: constitutional democracy; content neutrality; freedom of speech; tolerance; equity. no caso dos atos da fala assertivos, isto é, de asserções de fatos e valores que o falante acredita que sãoverdadeiras ou corretas; mesmo quando soe ultrajante, asserir algo não implica violação de direito alheio, mas significa o exercício do próprio direito.

Palavras-chave: democracia constitucional; neutralidade de conteúdo; liberdade de expressão; tolerância; equidade.

\section{CONTENTS}

1. Introduction: a critical question; $\mathbf{2}$. The false cry of fire; $\mathbf{3}$. Speech and expressive value; 4 . Free speech and democracy; $\mathbf{5}$. Free speech and truth; $\mathbf{6}$. Free speech and autonomy; $\mathbf{7}$. Free speech and tolerance; 8. Constitutional neutrality; $\mathbf{9}$. Free speech and equality; $\mathbf{1 0}$. Speech and action; 11. Conclusion: an enlightening case; 12. References.

\section{INTRODUCTION: A CRITICAL QUESTION}

Constitutional democracy is a way of organizing relations between government and individuals inside national states. It is essentially characterized by the acceptance of a written or unwritten constitution that performs as a higher law and guarantees even against governmental powers certain human rights that, according to historical and rational agreement, people may never be deprived of, such as life, freedom, property, equality, due process and vote. Freedom of speech is probably the brightest star in the constellation of constitutional rights.

In a first approach, freedom of speech could be defined as a principle according to which individuals must have the liberty to hold and express ideas through oral language and writing, symbolic gestures or images, in any platform and concerning a variety of matters, from politics to religion, economy to history, without fearing or suffering censorship or punishment. However, despite of what this broad concept might suggest, freedom of speech is not conceived anywhere as a right that grants protection to everything that can be uttered. In free speech American legal doctrine, for instance, it is very well known the famous adage of US Supreme Court Justice Oliver Holmes, who proclaimed long ago that "the most stringent protection of free speech would not protect a man in falsely shouting fire in a theatre and causing a panic"1. This old sentence expresses a view that remains as one of the most powerful in free speech thinking and ruling everywhere: freedom of speech is limited, it does not cover all kinds of speech.

Some crimes committed with the use of language - like threats, slander, false alarms, harassment, conspiracy or blackmail - are considered unworthy of protection without contention. It seems they don't even get to fit into a satisfactory concept of

Schenck v. United States. Supreme Court of the United States. 249 U.S 47 (1919). 
speech. But there are some other kinds of speech that raise serious controversy. Is the government allowed to prohibit the so-called hate speech, a flag burning demonstration, disclosure of classified information, civil disobedience advocacy, statements against gay marriage? Or would such a ban impose an unconstitutional constraint on speech? These are dilemmas that every democracy must face.

There are no easy answers. First, competitive values seem to be in contradiction sometimes. Hate speech cases, for example, bring to the debate the tension between the need of protecting individual autonomy and the commitment in defending racial, religious or sexual groups. Beyond that, language is a complex phenomenon. There are endless things people can say with the most different styles, intonation, motives and intentions, in the most diverse situations and settings. Hate speech itself is not a univocal category. As Kent Greenawalt observes, "criticizing Jews in a classroom discussion or in the middle of campus is not the same as reviling a Jewish student in his room or posting an anti-Semitic sign opposite his door"2. So, should we treat both speech in the same way? Should all hate speech be banned or protected, or only a part of it? Could we accept general racist assertions, but not personal targeted vilification?

To make things a little harder, constitutional stipulations are not able to provide solution for all possible situations of contentious speech. Generally, free speech constitutional clause is written in brief and open terms. Constitutional language does not usually refer to unprotected categories in an exhausting way or with enough specificity. American Constitution, for instance, dictates that "Congress shall make no law [...] abridging freedom of speech, or of the press" and nothing more. For this reason, in liberal legal systems judges have been called to fill the normative emptiness and to determine free speech limits in the context of controversial cases. It is a task that requires wisdom because of what is at stake in the decision-making process.

In fact, the question about how far to protect and how far to restrict speech is a critical one for democracy. Somebody who says something eventually forbidden is not only saying something inappropriate, unpleasant or repulsive, is not only challenging a good manners book. He is breaking the law, he is making something illegal, something that exposes him to official and severe consequences, such as civil liability or criminal penalty. So, defining protected and unprotected speech means to draw a line between speech that may be punished and that may not, between speech that may be used to send a man to jail or to take away his money and that may not, between speech that may be banned from public debate and that may not. It is not about defining good or bad ideas, polite or impolite speech, but rather than that, it's about separating lawful from unlawful speech, with the good and the bad consequences attached.

2 GREENAWALT, Kent. Fighting words: individuals, communities, and liberties of speech. New Jersey: Princeton University Press, 1995, p. 73. 
Constitutional courts should be very cautious in interpreting and implementing the free speech constitutional clause. It is of utmost importance to create clear, simple and stable rules, capable of indicating without uncertainty and in advance what, after all, citizens are allowed or forbidden to say, or what the government is entitled to ban and punish concerning speech. In line with the basic principle of the Rule of Law, people have the right to prior knowledge about what is right and wrong, and a rhetorical, imprecise or hesitant judicial ruling on freedom of speech tends to generate self-censorship and opens the door forex post facto punishments.

The present essay seeks to explore the essential meaning of freedom of speech in the context of contemporary democracy and aims at answering the question about how free speech constitutional clause should be understood. The intention here is not to describe the constitutional law of particular jurisdictions, but to propose a concept of freedom of speech consistent with the ideals of any government that claims to be democratic. Although involving a personal way to see the things, the following ideas are certainly influenced by a set of judicial precedents and correspond to a dominant philosophical viewpoint. In order to accomplish our goals, it seems a good idea to begin considering Oliver Holmes's analogy on the false cry of fire.

\section{THE FALSE CRY OF FIRE}

In 1917, the United States got into the World War I. Under an atmosphere of patriotism around the country, President Woodrow Wilson proposed, and the Congress approved the Espionage $\mathrm{Act}^{3}$. This legislation made it a crime to cause, attempt to cause or conspire to cause insubordination in the American military or obstruction of military recruitment ${ }^{4}$. At the time, Americans could not turn down calls for war. Charles Schenck, then secretary general of the Socialist Party in Philadelphia, had distributed pamphlets comparing conscription to slavery and urging conscripts to reject fighting a war on behalf of Wall Street interests.

Prosecuted and convicted on charges of attempting to cause insubordination and to obstruct recruitment, Schenck appealed to the Supreme Court claiming that the First Amendment to the United States Constitution does not allow Congress to pass any law restricting freedom of speech. However, the Supreme Court, without dissent, upheld the conviction. The leading opinion came from Oliver Wendell Holmes. He admitted that, in normal times, Schenck's words would be protected but not in times of war. He pointed out that "the character of every act depends upon the circumstances

\footnotetext{
3 See: LEWIS, Anthony. Freedom for the thought that we hate: a biography of the First Amendment. New York: Basic Books, 2007, p. 25.

4 See: FALLON, Richard H. The dynamic Constitution: an introduction to American Constitutional Law. Cambridge University Press, 2004, p. 34.
} 
in which it is done" and that "the question in every case is whether the words used are used in such circumstances and are of such a nature as to create a clear and present danger that they will bring about the substantive evils that Congress has a right to prevent". This view implied a non-absolutist reading of the apparently inflexible words of the First Amendment and, to support it, Holmes produced his famous analogy: "the most stringent protection of free speech would not protect a man in falsely shouting fire in a theatre and causing a panic ${ }^{\prime \prime}$.

Schenck versus the United States is no longer an active precedent. The "clear and present danger" formula was too vague and could be easily manipulated. According to Kent Greenawalt, in a case decided the following week by the Supreme Court ${ }^{6}$, a man was punished for helping to publish twelve articles of small-circulation according to which the resistant recruits, tough "technically wrong", were more victims of a sin against themselves than sinners. "Thousands of people were convicted and sent to jail during World War I for comments no stronger than this" ${ }^{17}$. Perhaps, that is why in Abrams versus the United States ${ }^{8}$ Holmes himself rearticulated his arguments and introduced more demanding conditions for punishing speech ${ }^{9}$; in Whitney versus California ${ }^{10}$ Louis Brandeis set an even more restrictive position. The dissenting votes ${ }^{11}$ of Holmes and Brandeis, in these two cases, became memorable and had significant influence in the development of the modern American legal doctrine regarding subversive speech. In 1969, in Brandenburg v. Ohio ${ }^{12}$ (without Holmes and Brandeis at the time) the Supreme Court took a new legal opinion under which Schenck would not have been convicted, if earlier available.

Then, what may seem intriguing is that although the reasons that led to Schenck's conviction no longer exist or would not be enough now, Holmes's analogy on the false cry of fire still stands as an axiom about free speech limits. How to understand that? The reason is simple but not always perceived. Between a false cry of fire in a crowded theater to induce panic and the messages contained in the leaflets distributed by Schenck there is a huge difference. The analogy supposed by Holmes does not exist,

\footnotetext{
Schenck v. United States. Supreme Court of the United States. 249 U.S 47 (1919).

6 Frohwerk v. United States. Supreme Court of the United States. 249 U.S. 204 (1919).

7 GREENAWALT, Kent. Fighting words: individuals, communities, and liberties of speech. New Jersey: Princeton University Press, 1995, p. 17-18.

8 Abrams v. United States. Supreme Court of the United States. 250 U.S. 616 (1919).

9 See: SHAPIRO, Martin. Freedom of speech: the Supreme Court and judicial review. New Jersey: Prentice-Hall, Inc., 1966, p. 49.

10 Whitney v. California. Supreme Court of the United States. 274 U.S. 357 (1927).

11 From a formal point of view, Louis Brandeis' opinion did not constitute a disagreement since, for procedural reasons, he maintained the appellant's conviction. However, his views about free speech have revealed a profound dissent from previous Supreme Court decisions.

12 Brandenburg v. Ohio. Supreme Court of the United States. 395 U.S. 444 (1969).
} 
and therefore, it is entirely acceptable that between the two communications one may deserve protection while the other does not.

According to Alan Dershowitz, the false cry of fire in a crowded theater is probably the only legal analogy to receive the status of a popular argument in the United States. It is, he says, an analogy often invoked when people try to get the government to censor any kind of speech that they deem unacceptable. However, still according to him, "in spite of its hallowed position in both the jurisprudence of the First Amendment and the arsenal of political discourse, it is and was an inapt analogy, even in the context in which it was originally offered"13. The context to which Dershowitz refers is precisely the Schenck case, and it is important to follow his criticism to understand why the false cry of fire is not worthy of protection.

Dershowitz makes two essential remarks. First, Schenck's leaflets contained a political message that encouraged recruits to think about it and then, if they wished, to act in a non-violent manner. The man who shouts fire in a crowded theater is neither sending a political message nor inviting his readers to think about it and decide what to do in a rational, calculated way. "On the contrary, the message is designed to force action without contemplation. The message 'Fire!' is directed not to the mind and the conscience of the listener but, rather, to his adrenaline and his feet. It is a stimulus to immediate action, not thoughtful reflection"14. In this sense, the cry of fire is not even speech; it is "a clang sound", the equivalent of a non-verbal alarm that triggers an automatic response, different from that of political rhetoric.

Secondly, the cry in question is dishonest, once the speaker knows that there is no real fire. The messages contained in Schenck's leaflets, however, cannot be blamed of having the same flaw, it is to say, of being the result of a conscious and intentional lie. Schenck sincerely expressed political ideas about the war, ideas that are true in the perspective of the speaker's mind, and as the United States Supreme Court came to reaffirm in Falwell versus Hustler, "the First Amendment does not recognize such a thing as a false idea"15. For these reasons, Dershowitz thinks Holmes analogy in the Schenck case is not only inappropriate but also insulting ${ }^{16}$.

In fact, it seems that the false cry of fire is something that is done by saying, not something that is only said. Whoever falsely shouts fire knowing there is no fire at all does not really asserts or warns about anything, but rather pretends to make it, faking

13 DERSHOWITZ, Alan M. Shouting Fire: Civil Liberties in a Turbulent Age. Little, Brown and Company, 2002, p. 143.

14 DERSHOWITZ, Alan M. Shouting Fire: Civil Liberties in a Turbulent Age. Little, Brown and Company, 2002, p. 143-144.

15 Hustler Magazine v. Falwell. Supreme Court of the United States. 485 U.S. 46 (1988). See also: Gertz v. Robert Welch Inc. Supreme Court of the United States. 418 U.S. 323 (1974).

16 DERSHOWITZ, Alan M. Shouting Fire: Civil Liberties in a Turbulent Age. Little, Brown and Company, 2002, p. 144-145. 
to believe and intending to deceive the listeners. This is more acting than expressing. Only pay attention to the grammar: the verbs "lie", "fake", "pretend" and "deceive" denote deeds, or acts of misrepresentation, a kind of fraud, and not, in a proper sense, communicative acts of thoughts and beliefs.

The problem with the false cry of fire is not the content of the message, but the behavior of the speaker, is not the inaccuracy of the sentence, but the insincerity of the utterer. If there was a real fire, nobody would qualify shouting as a misconduct. If there wasn't a real fire, but the speaker thought there was (because of defective perception or amid a delirium crisis), it is hard to imagine he could be punished since shouting would only be a manner of speaking his mind, a way of speaking about something he believed to be true, although it was not.

\section{SPEECH AND EXPRESSIVE VALUE}

In constitutional democracy, as we know, speech is often restricted by statutory law. Speech is a target that never gets out of reach. However, since there are cases in which restrictions are easily and widely accepted (as it happens about criminal offenses like encouragements to suicide), but there are others in which restrictions are seriously questionable (as it happens with religious statements against gay marriage), it is supposed that there might be some attribute related to the type of the speech that makes the difference. What would it be?

Even recognizing that every speech has singularities and needs to be considered on a case-by-case basis, it is possible to isolate a general point of discordance between the quiet and the controversial cases of speech restriction. The contrast between the false cry of fire in a crowded theater and the message contained in Schenck's leaflets is useful to illustrate the difference. Simply, what happens is that the false cry of fire has no expressive value or does not fulfill any expressive function, and precisely for this motive, according to an assumption universally shared, it is not reached or covered by free speech constitutional clause. The note of distinction resides, therefore, in the concept of expressive value. The basic idea is as follows.

As it is normally understood, free speech grants protection no matter the content of the message. Free speech prohibits government to censor or punish speech based on the supposed incorrectness of what people think and say. In this case, it is intuitive that speech is protected because it is supposed to be valuable for reasons other than the substantive qualities of the message. Imagine, for instance, that the congress is about to pass an act on the use of embryonic cells for research purposes. If everyone can freely argue, against or in favor, it is because it is expected, among other things, that a better political deliberation can be found if the voices from side to side are listened. Speech is protected because it seems important despite the orientation of the ideas. It 
does not matter if one's opinion is not the best or the wiser, but just that it somehow enriches the public debate. In this sense, having expressive value only means that the speech plays an expressive role in the process of discussion.

In synthesis, there are five major arguments on why freedom of speech is valuable no matter the content of the ideas. We can summarize them by borrowing a few words from Greenawalt ${ }^{17}$. The first(democracy) proposes that free speech promotes the functioning of democracy, which is based on the concept of self-government. Citizens must be free to openly speak and listen to better exercise their sovereign functions. The second (truth) proposes that open discussion promotes the discovery of the truth and the progress of knowledge. The claim is that truth and knowledge are most likely to emerge from the collision of ideas. The third (autonomy) proposes that free speech promotes individual autonomy, mainly because it allows people to enjoy information and opinions important for them to make up their own minds instead of living by the dictates of others. The fourth (tolerance) proposes that free speech promotes tolerance. If the speech rights of dissenters and radicals are granted, the lesson addressed by society is that everyone should be tolerant with those who think different. The last one (equality) proposes that if men are all equal in dignity, it would be wrong to prevent only some ideas to be expressed, once this would mean that the ones who hold them are less dignified than others.

Speech has expressive value when it reaches some of these reasons; when none of them is applicable, speech simply lacks expressive value. The false cry of fire lacks expressive value because it is not the kind of assertion apt to be a part of any intellectual dispute around truth, it is not a way of engaging in the democratic process, or participating in political life, it is not a way of affirming or improving individual autonomy, it is not a way of exercising equal rights and, not enough, it is not compatible with a demand for tolerance.

The leaflets of Schenck were different. First, thinking and saying that conscription is a form of slavery is to make a genuine assertion, that is, to enunciate seriously and literally a proposition about the world (or some state of affairs) believed to be true and intended to be taken as such. Second, thinking and suggesting recruits to refuse the draft may be taken as an exhortation (a directive speech act), that is, as saying something to get others to act, but even so, it is not the case of incitement to violence, nor of advocating illegal activities, once deciding not to join the army, in the speaker's mind, is no less than an individual right. In the end, it seems that Schenck's message was a complaint for political changes based on his sincere beliefs about unfair burdens on young American citizens. Here, all free speech values apply.

17 See: GREENAWALT, Kent. Speech, crime, and the uses of language. New York: Oxford University Press, 1989, p. 9-39. 
Having expressive value is the first requirement for a speech to be deemed worthy of protection. It would be an exaggeration to immunize messages to which none of the reasons underlying free speech clause is applicable, as it happens with the false cry of fire. Accordingly, to determine whether a given speech has expressive value is vital for investigating the adequacy of some restriction upon it in constitutional democracy.

Of course, the concept of expressive value asks fora more comprehensive consideration, and at this point political philosophy is the best companion one can find ${ }^{31}$. Constitutional provisions proclaim the rights, but their justifications are generally submerged; they are not on the surface, but in the depths of the human thinking. Eric Barendt rightly points out that "a constitution may reflect commitment to a general concept of freedom of speech, but the particular understandings or conceptions of that freedom are best elucidated by an examination of the moral and political reasons justifying its protection"18. So, let's take a closer look on them.

\section{FREE SPEECH AND DEMOCRACY}

Free speech is commonly thought to promote democracy. Democracy rests on the principle of self-government, whereby political decisions ultimately belong to citizens either directly or through representatives. In the logic of the system, freedom of speech fulfills central functions, such as allowing voters to make informed choices in elections. Also, thanks to freedom of speech, people can influence public policies, and authorities are subject to criticism that may lead to their replacement. Abuse of power and corruption can be denounced and maybe prevented by fear of revelation. Beyond that, conflicting interests in the community are identified and accommodated in favor of social stability, and individuals and minorities that openly dissent may relieve frustrations and do not need to use violence as an alternative to get power, to fight government programs or to gain attention for reformist claims. Finally, better political deliberations should be taken with the audience of all sides of debate.

The connection between freedom of speech and democratic process is the basis of some influential essays written by Alexander Meiklejohn regarding the Constitution of the United States ${ }^{19}$. In line with his ideas, in New York Times versus Sullivan, one of the most acclaimed precedents of modern American legal doctrine concerning freedom of speech, the US Supreme Court referred to the ability to criticize the government and its

\footnotetext{
18 BARENDT, Eric. Freedom of Speech. 2. ed. New York: Oxford University Press, 2007, p. 3.

19 MEIKLEJOHN, Alexander. Political freedom: the constitutional powers of the people. New York: Oxford University Press, 1965, 164 p. See also: Free speech and its relation to self-government (1948); What does the First Amendment mean? (1953); Testimony presented before the Subcommittee on Constitutional Rights, United States Senate Committee on the Judiciary (1955); The First Amendment is an absolute (1961). In: BLASI, Vincent. Ideas of the First Amendment. St. Paul: Thomson West (American Casebook Series), 2006, p. 747-756; p. 757-760; p. 760-772; p. 772-778.
} 
agents as constituting "the central meaning of the First Amendment" ${ }^{\prime 20}$.When the case was decided holding that civil liability of the press (in the event of inaccurate news) requires actual malice, and not merely negligence, Meiklejohn even said that it was "an occasion for danclng In the streets" ${ }^{\prime 21}$.

The rationale of democracy is subject to questioning. Does free speech really give voice to everyone in a world with economic inequalities? According to Owen Fiss, "the rich may, for example, so dominate advertising space in the media and other public domains that the public will, in effect, hear only their message, and as a result, the voice of the less affluent may simply be drowned out"22. Moreover, mass media are under the control of few people because newspapers and magazines demand a high cost of operation, and the waves of radio and television have limited availability. Those who have them have a higher power of influence. However, even if we are here before undeniable facts, it seems that none of them can make freedom of speech less important within the framework of democratic government.

The concept of democracy is impractical if citizens do not have the right to speak and listen freely. Distortions of power are relevant, and the challenge is to search for alternative means of compensating them positively or giving voice for those who doesn't have it. But even if free speech seems to have more formal than real dimension in contrast with mass media holders, it does not mean it has no utility, or that it is not an instrument for the exercise of political rights. Besides, it is supposed that the press itself is many times the voice of the people.

Anyway, the Internet significantly changed the scenario. Things are not anymore as in the last century, in which people found themselves mostly in the passive side of the communicative relationship. Jack Balkin describes the new paradigm as it follows: “Internet speech is participatory and interactive. People don't merely watch (or listen to) the Internet as if it were television or radio. Rather, they surf through it, they program on it, they publish to it, they write comments and continually add things to it. Internet speech is a social activity that involves exchange, give and take. The roles of reader and writer, producer and consumer of information are blurred and often effectively merge ${ }^{\prime 23}$. So, maybe the Internet has not replaced the mass media, but the distribution of the power to communicate seems already less unequal.

\footnotetext{
20 New York Times v. Sullivan. Supreme Court of the United States. 376 U.S. 254 (1964).

21 KALVEN, Harry. The New York Times Case: a Note on the "Central Meaning of the First Amendment. In: BLASI, Vincent. Ideas of the First Amendment. St. Paul: Thomson West (American Casebook Series), 2006, p. 788.

22 FISS, Owen M. The Irony of Free Speech. Cambridge: Harvard University Press, 1996, p. 16.

23 BALKIN, Jack M. Digital Speech and Democratic Culture: A Theory of Freedom of Expression for the Information Society. In: BLASI, Vincent. Ideas of the First Amendment. St. Paul: Thomson West (American Casebook Series), 2006, p. 834.
} 
In connection with democracy, freedom of speech tends only to justify the coverage of ideas and messages with political content or interacting in the political process. So, if democracy was the only basis for protecting freedom of speech, things like self-help literature, commercial advertising, sports journalism and entertainment magazines would be left out of perspective. More important: the same could happen with allegedly defamatory or invasive statements. Probably, these types of speech would be understood as not belonging to the constitutional worries, and in this case, greater or lesser freedom related to them would then depend on the legislative power. But this is not how things are: freedom of speech is valued for reasons other than democracy, and then, it justifies much more than just political messages.

\section{FREE SPEECH AND TRUTH}

In On liberty, Stuart Mill claims that speech must be protected for the sake of clarifying the truth. According to him, the suppression of ideas is a crime committed against present and future generations. "If the opinion is right, they are deprived of the opportunity of exchanging error for truth; if wrong, they lose [...] the clearer perception and livelier impression of truth, produced by its collision with error"24. Moreover, according to Mill, between conflicting doctrines none of them are wholly false or exact, and each contains a portion of error and truth, so that truth will often result from the sharing between them ${ }^{25}$. Thus, free speech enables mankind to replace long-held misconceptions, as well as to test and revitalize truths that would be, otherwise, no more than dead dogmas. In essence, as Erwin Chemerinsky said, "the argument is that truth is most likely to emerge from the clash of ideas" 26 .

Thomas Emerson stresses that the truth rationale applies regardless of how false and harmful an idea appears to be. On the one hand, he writes, "many of the most significant advances in human knowledge - from Copernicus to Einstein - have resulted from challenging hitherto unquestioned assumptions", so that no opinion should ever be deemedirrefutable. On the other hand, "the unaccepted opinion may be true or partially true, and there is no way of suppressing the false without suppressing the true". Last of all, "even if the new opinion is wholly false, its presentation and open discussion serves a vital social purpose" because it provokes the reappraisal of the settled opinion and leads to a deeper understanding of its evil meaning ${ }^{27}$.

\footnotetext{
24 MILL, John Stuart. On liberty. In: BLASI, Vincent. Ideas of the First Amendment. St. Paul: Thomson West (American Casebook Series), 2006, p. 327.

25 MILL, John Stuart. On liberty. In: BLASI, Vincent. Ideas of the First Amendment. St. Paul: Thomson West (American Casebook Series), 2006, p. 347-348.

26 CHEMERINSKY, Erwin. Constitutional law: principles and policies. New York: Aspen Publishers, 2006, p. 927.

27 EMERSON, Thomas I. Toward a general theory of the First Amendment. New York: Random House, Inc., 1966, p. 7-8.
} 
The pursuit of truth is important as a means for the progress of humanity and individuals. For practical purposes, it is important to know, for example, whether the decisive factor for the reduction of the ozone layer is the burning of fossil fuels or the destruction of forests; what level of security the financial market is offering; what kind of influence movies of explicit brutality have on child psychology; from which moment the fetus in the mother's womb begins to feel pain; whether or not there is an epidemic outbreak or increased violence in a requested tourist destination. Relevant social, business and personal decisions may depend on what is concluded, and, at least in principle, it is believable that responses that are more reliable or closer to the truth will be obtained if there is room for discussion and confrontation rather than suppression of opinions and information that governments might anticipate as false.

Truth rationale justifies coverage for a wide range of subjects (history, business, morals, literature, science, etc.), going beyond protection for speech with political content, or engaged in the democratic process. Although it seems to fit better in the context of controversies about objective facts, it does not fail to support the debate around purely moral valuations such as "capitalism is unjust". Moreover, as in the case of democratic justification, truth rationale also supports dissent, even the most secluded one. In the words of Stuart Mill: "If all mankind minus one were of one opinion, mankind would be no more justified in silencing that one person, than he, if he had the power, would be justified in silencing mankind" 28 .

The decisive premise is that government is not entitled to sanction an official orthodoxy, defining what is right and wrong in politics, morals, history, archeology, economics, etc. Official doctrines against which is not allowed to argue under the risk of punishment are almost always suspect. Those who impose them not only lack the gift of infallibility but also are less interested in discovering the truth than in preserving their positions and fortune. Truth certainly has better changes when heresy and blasphemy are crimes that no law dares to recognize.

Like the democratic justification, the truth rationale is not immune to objections. It is said there is sometimes the risk that atrocious doctrines, undisputedly false, may triumph among citizens, as they did in Nazi Germany after Hitler came to power in 1933, causing the genocide of six million Jews. Some contemporary democracies, believing so, came to prohibit the dissemination of ideas of racial superiority, making hate speech a crime. Nevertheless, even in those jurisdictions, hate speech seems to be a lonely exception to the general principle that freedom of speech in democracy is incompatible with a system of official truths. It seems, indeed, a singular case of content-based restriction, perhaps one understandable in the face of some local context and

28 MILL, John Stuart. On liberty. In: BLASI, Vincent. Ideas of the First Amendment. St. Paul: Thomson West (American Casebook Series), 2006, p. 327. 
historical traumas. However, the major proposition still stands: government is not the owner of the truth and cannot suppress ideas because they are allegedly false.

\section{FREE SPEECH AND AUTONOMY}

Free speech is commonly taken as an imperative of human condition. If what decisively distinguishes man in the world of living creatures is the reasoning ability, the integral fulfillment of each person's humanity implies the exercise of his rational faculties in fullness. It requires, first of all, freedom to think autonomously, or freedom of conscience. By freedom of conscience is designated a sphere of intellectual deliberation under the exclusive domain of the individual, within which are ideas that, even sounding unfounded to others, are recognized as legitimate while belonging to a man and insofar as corresponding to the most significant of his vocations.

In practical terms, external control over the mind of others is not easy to attain. A man whose ideas are abhorred by the dominant power may be forbidden to say, under threat of penalties, what he thinks or be forced to say what he does not believe, and even doing so to save his life, in silence he can think what he actually thinks. Coercion will be enough to hinder speech and action but not to change his mind. The innermost secret of his consciousness is beyond reach; it is a land to which he alone has access. Frederick Schauer tells that prisoners in Nazi concentration camps used to sing a song called Melne Gedänke SInd Frei ("my thoughts are free") ${ }^{29}$.It is possible that by chanting some of them gathered moral strength that helped to resist and survive, above all, through the perception that although degraded to inhuman conditions, there was still in them a last and essential remnant of humanity, precisely their consciences, an invincible force even for the most totalitarian power.

Of course, it would not make sense to assure something like a right to think silently. In a normative perspective, the object of a freedom must be something susceptible to prohibition. However, thinking in silence is a de facto freedom, a mental phenomenon whose ban is impossible and ineffective. Therefore, to begin with, granting individuals the right to think in silence is not even logically bearable. Besides, allowing someone to think, as long as keeping thoughts quiet, means declaring the thoughts in question illicit. Finally, respect for human condition requires more than tolerating only a precarious use of rational faculties, such as developing an inner monologue as a resource to maintain self-consciousness. This can be useful for psychological defense in extreme situations, but it is legally insignificant.

Freedom of conscience implies more than superfluous consent of secret ruminations. It means that our thoughts, whether wise or not according to others, rightfully

29 SCHAUER, Frederick. Free Speech: A Philosophical Enquiry. In: BLASI, Vincent. Ideas of the First Amendment. St. Paul: Thomson West (American Casebook Series), 2006, p. 849. 
belong to us. In a double sense: we are worthy of thinking by ourselves and our thoughts are worthy of appropriation. Thoughts we have are, therefore, lawfully possessed. Moreover, once integrating man's personality, thoughts are not exposed to any form of expropriation. The first consequence is that freedom of conscience consists of an excludendi alios right, that is, a right that excludes the right of others of intending to dominate the owner's mind, dictating what to believe, what to feel or what to like. The second consequence is that the owner has the privilege to use what is his, which includes the power to express himself, mainly to communicate to others what he believes, understands, feels, perceives or prefers. So, freedom of conscience understood as such inevitably implicates freedom of speech as a result of man's property on himself.

At the same time, autonomy depends, though not exclusively, on freedom of speech to be maximized. Schauer teaches that ideas are not static, they regularly change, evolve, and refine. Thought is a process, and its main instruments are language and communication. "Minds do not grow in a vacuum. Intellectual isolationism is almost wholly inconsistent with intellectual development. The image of the mountaintop guru, developing great ideas in a sublime and isolated existence, is far more myth than reality"30. Schauer emphasizes that linguistic communication is significant for the intellectual growth of man, both as speaker and as listener. Often someone has an incipient idea, but sees it develop or perceive its weaknesses at the first moment when it needs to be intelligibly transmitted to another person. According to Schauer, communication helps those who communicate to clarify and better understand their thoughts. On the other hand, listening, reading and seeing what others have to say puts a man in touch with a wide variety of opinions and information that he may not be able to imagine or articulate alone. In this case, says Schauer, communication offers the chance to practice the vital talent of evaluating and choosing between ideas ${ }^{31}$. Participating in communicative relationships is, therefore, a way of elaborating, understanding, and optimizing the ability to think.

For the constitutional law, which disciplines relations between individuals and the government, the implication between freedom of conscience and freedom of speech has a very specific meaning. In the words of Charles Fried, "freedom of mind [...]places firm limits on government's power to interfere with my liberty to think as I choose, to express my thoughts to others, and to receive their expressions in turn", as well as to decide what to learn, hear, read, and see $^{32}$. Likewise, Fried adds, it prevents

30 SCHAUER, Frederick. Free Speech: A Philosophical Enquiry. In: BLASI, Vincent. Ideas of the First Amendment. St. Paul: Thomson West (American Casebook Series), 2006, p. 850-851.

31 SCHAUER, Frederick. Free Speech: A Philosophical Enquiry. In: BLASI, Vincent. Ideas of the First Amendment. St. Paul: Thomson West (American Casebook Series), 2006, p. 851.

32 FRIED, Charles. Saying What the Law is: The Constitution in the Supreme Court. Cambridge: HarvardUniversity Press, 2005, p. 79 e p. 81. 
the government not only from suppressing thoughts and speech "but also against the government's putting words in your mouth, compelling you to print what you do not want to print, affirming what you do not believe". Freedom of conscience is, in synthesis, "freedom from government mind control"33.

\section{FREE SPEECH AND TOLERANCE}

In The Tolerant Society, Lee Bollinger highlighted the teaching of tolerance as a reason for protecting speech. He starts from the premise that societies tend to follow and impose uniform ideas and practices and to be severe with dissenters, acting against them not only through legal penalties such as imprisonment but also through informal modes of punishment such as stigma and isolation. Stuart Mill also gave importance to this topic. According to him, social oppression is even more ruthless than legal oppression because although it is not based on extreme punishments, it leaves fewer ways to escape. In Mill's view, human societies are predisposed to compel people to adjustment, curbing development and, if possible, preventing the birth of any individuality in disharmony with its models ${ }^{34}$.

Bollinger accepts the opinion about the tendency for inflexibility and the heaviness of social oppression. "To have it said that you were once a communist sympathizer, a fascist, atheist, or a liar can make you, at least in most quarters within the society, socially and economically a pariah, as destitute as if you had been thrown in prison and fined"35. However, according to Bollinger, social hostility is often at the basis of legal punishments. "If there is a problem of a tendency to excessive intolerance [....], it would seem to be not with the 'government' alone but with 'the people' as well, acting through their government" ${ }^{\prime \prime 36}$. One of the most dramatic passages in the history seems to prove it. The torture and killing of Jesus Christ were formally consented by Pontius Pilate, procurator of the Roman emperor in Judea, but he acted reluctantly. According to the Gospel of John, Pilate washed his hands and delivered Jesus to martyrdom, but the one who imposed the outcome, at the risk of revolt, was the crowd in front of the Praetorium.

According to Bollinger, freedom of speech does the job of making people aware of the need for tolerance. If minorities and dissidents are free to express what they think, the message addressed will be that respecting differences is a virtue. Free speech aims at educating for tolerance, that is, for the development of the social capacity to control the impulse to domesticate and, especially, to punish the divergent because of

\footnotetext{
33 FRIED, Charles. Saying What the Law is: The Constitution in the Supreme Court. Cambridge: HarvardUniversity Press, 2005, p. 82 e p. 85.

34 MILL, John Stuart. On liberty. In: BLASI, Vincent. Ideas of the First Amendment. St. Paul: Thomson West (American Casebook Series), 2006, p. 320-321.

35 BOLLINGER, Lee C. The tolerant Society. New York: OxfordUniversity Press, 1986, p. 109-110.

36 BOLLINGER, Lee C. The tolerant Society. New York: OxfordUniversity Press, 1986, p. 79.
} 
their beliefs and convictions. A tolerant society is one that renounces the aspiration to coerce and harass by formal or informal means those who profess supposedly objectionable ideas, whether political, moral or religious.

The rationale of tolerance also suggests that intolerance is somewhat useless because human mind is ultimately irrepressible. Pretending to dominate the conscience of dissidents should not be an objective for the government because it is not even feasible. Baruch de Espinosa, in his Tractatus Politicus, had already argued that a man could never be led to believe in what is contrary to his feelings and thoughts, to love what he hates or hate what he loves. According to him, the consequence is that all actions to which no one can be incited by promises or threats are outside the government purposes. No one, for example, can abdicate his ability to judge. The law that would try to compel human mind would be nothing but a delusion ${ }^{37}$.An analogous opinion is found in John Locke's Letter on Tolerance. He thinks that no one may believe under the prescription of another. The nature of human understanding cannot be constrained by external forces. Confiscating property or tormenting the body with captivity and torture will be in vain if, through these torments, man in power want to deprive a man from his faith and beliefs ${ }^{38}$.

In addition, the argument of tolerance holds that more dangerous than granting free speech is subjecting speech to repressive controls. If force is futile and ineffective to constrain conscience, its employment will eventually provoke the resistance of true believers, and instead of harmony and concord there will be revolts, perhaps bloody ones. The religion wars that have swept Europe since the Reformation are attributed more to the persecutions of schismatics and heretics than to the diversity of faith among men. Therefore, from a pragmatic point of view, intolerance is regarded as more dangerous to social order than tolerating speech that is allegedly false or pernicious. At worst, tolerance would be a minor evil, a way to replace the power of the sword with "a form of hospitality" ${ }^{139}$, giving peace a better chance.

The inability to submit human mind and the danger of violent resistance are reasons for political prudence against intolerance. In L'età Del Diritti(The Age of Rights), Norberto Bobbio claims that there are some noble reasons for tolerance. Tolerance implies exchanging methods of force by techniques of persuasion as a way of resolving conflicts; also, tolerance is an inherent necessity to the very nature of truth, which is not one and has many faces; and tolerance expresses our respect for others trough the recognition of every man's right to believe according to his own conscience ${ }^{40}$. Thus,

37 ESPINOSA, Baruch de. Tratado Político. São Paulo: Abril Cultural, 1983, p. 314-315.

38 LOCKE, John. Carta Sobre a Tolerância. Lisboa: Edições 70, 1987, p. 92-93.

39 TINDER, Glenn. Tolerance and Community. Columbia: University of Missouri Press, 1995, p. 237.

40 BOBBIO, Norberto. A Era dos Direitos. 8. ed. Tradução de Carlos Nelson Coutinho. Rio de Janeiro: Campus, 1992, p. 208-210. 
tolerance is not only convenient but the one option consistent with democratic governments, the search for truth and individual autonomy.

\section{CONSTITUTIONAL NEUTRALITY}

When freely speaking is a way of engaging in political life, of deepening, questioning and innovating our comprehension of the world, of expressing mental states, such as beliefs and feelings, or of indirectly educating individuals for tolerant behavior in social relations, speech is deemed valuable and worthy of protection just for performing a role by which free speech is cherished. So, the logical implication is this: the constitutional safeguard of freedom of speech is neutral as to the content of the speech, or the content of ideas.

The principle of neutrality means that a message has expressive value whatever the topic in question is. Any subject is worthy of being addressed: abortion, reincarnation, sodomy, Marxism, revolution, death penalty, adultery, and witchcraft. There are no proper and improper matters. There are no taboos. Also, having expressive value does not depend on the viewpoint. Being in favor (pro-choice) or against (pro-life) abortion makes no difference. Besides, saying something with expressive value does not depend on sounding good to others or being politically correct. It is allowed to spoil modesty, to challenge the unquestionable, to confront the dominant ethics. People are not confined only in sympathetic, condescending, virtuous, traditional opinions, nor only do have to speak with elegance and softness. Moreover, having expressive value does not require speech to be reverent to authorities or allied to government interests.

Constitutional neutrality leaves no room to distinguish between accurate and erroneous theories, intelligent and stupid comments, fair and unjust claims. In the eyes of third parties, lay people, scholars or authorities, some version of history may seem inexact, and the criticism of a literary work may sound unfounded. A religious feeling might seem foolish, an appeal for political reform might seem baseless. However, acceptance and receptivity are not conditions for protecting speech. The quality of what somebody says is undoubtedly a relevant predicate in science, philosophy, and religion. Constitutional law, however, does not separate in value the clever and the silly thinking. Freedom of speech indiscriminately values any speech compatible with the foundations of its protection. Provided that, however fragile, vulgar or unpleasant, speech is contained within the limits that allow it to be achieved by the underlying reasons of protection, it has expressive value.

If such a simple implication were not so neglected, some state judges in Brazil would not have done too much to ban the so-called Marijuana March in 2008. It was no more than a demonstration against anti-drug legislation, expected to occur in several capitals of the country. The value of the speech had nothing to do with the merit of the 
ideas. Whether or not the protesters were right or wrong and had or not a good cause did not matter at all. The only thing that counted is that they were citizens using their freedom to criticize legal canons and ask for new ones.

By the way, there is no difference between protesting against making marijuana use a crime and the law that imposes a tax, or that prohibits the naked in public. Somebody could argue that advocating drug release is tantamount to inciting a break of the law, and the adoption of criminal conduct. Nevertheless, it is an unfortunate mistake to confuse an appeal for changes in the law with a stimulus to break the law. Protesting the anti-drug law is not smoking or inciting smoking; it is only expressing beliefs and desires in harmony with free speech justifications. So obvious, the Supreme Federal Court reversed those injunctions, asserting that "the mere proposal of decriminalization $[\ldots]$ is not to be confused with the act of incitement to commit the crime, or with the laudation of the crime, since debating criminal abolition of certain punishable conduct can (and should) be carried out rationally, with respect among interlocutors, although the idea, for the majority, may be considered strange, extravagant, unacceptable or even dangerous" ${ }^{\prime 41}$.

Constitutional neutrality hugely spreads the scope of free speech. Under democratic perspective, for example, even ideas tending to sound degrading will be sheltered. Hypothetically, if before a bill about to pass in parliament supporting same sex marriage someone asserts that it is a shame to have the government encouraging "unhealthy and indecent unions", the message would be covered no matter the sexual prejudice it holds. Enacting legislation is the most genuine product of political agency. In a democracy, if some can argue in favor, others can argue against because all are equal in the right to choose a side and to speak about no matter the greater or lesser respectability of what they think and say. Since speech does not go beyond opposition to a legislative act, it is valuable and irrepressible.

Similarly, tolerance justification is not only applicable to the good and fair speech of minorities and dissenters against interests and practices of majorities and conservatives, which are considered backward and nefarious. It gives perhaps particular value to extremist thinking, one that almost any of us perceive as immoral and racist. A man's comment in an interview that he hates blacks, Muslims and Jews could be the case. However, if freedom of speech intends to promote tolerance, the protection of extremism best meets such scope because it has higher symbolic significance and pedagogical utility. It is easier to live with the speech of minorities and dissidents when the content is politically correct. Nevertheless, the profound meaning of tolerance only becomes accessible before the shocking and scandalous thought. To form a tolerant

41 ADPF 187. Supremo Tribunal Federal. Brasília, 2014. Available at: http://portal.stf.jus.br/processos/downloadPeca.asp?id=227098436\&ext=.pdf. Access: October 2018. 
society, which does not yield to the temptations to criminalize ideas under the pretext of being false or dangerous, requires pressing the tolerance principle to the extreme as a rule and without allowing casuistic manipulations. Moreover, if autonomy is a right, no man should be silenced under threat of legal punishment just because what he dislikes seems ignoble.

In the hypotheses described, free speech values undoubtedly apply. In the first situation, there is a moral argument against legalizing same sex marriage; in the second, there is a confession of aversion feelings toward some groups. Made in the assertive mode (not in incitement-to-violence, truly-threatening and fighting-words contexts, for instance ${ }^{42}$ ), these imaginary (but always possible) statements are both supported, respectively, by the values of democracy and autonomy, and indistinctly by the broader rationale of tolerance.

Examples of detestable ideas are not restricted to the terrain of prejudice. Imagine someone who publicly holds dictatorship as a superior form of political organization, terrorism as a legitimate way to fight imperialism, the natural right of man to trade in his organs, the sin of protected sex by condoms, woman's innate right to abort until the sixth month, criminal responsibility at ten years of age, the fairness of torturing war prisoners during interrogation. Even astounding, these ideas are worthy of protection in the light of free speech values.

\section{FREE SPEECH AND EQUALITY}

The contempt for the principle of neutrality would not only undermine the values of democracy, truth, autonomy and tolerance but would hurt a more general constitutional precept, according to which people are equal in dignity and, as such, must also be equal in respect. Even if free speech was not singular prerogative, the right to communicate ideas to others despite their content would work as an autonomous consequence of equality.

All are equal before the law, without distinction of any kind. With this traditional formula, many constitutions enunciate the principle of equality. The norm is a complex one. Its content is plural. However, there is a predominant meaning. The principle prevents the legislative power from making legal discrimination, that is, conferring some rights for some people and not conferring to others, or denying some rights for some and not refusing to others. Respecting human dignity is fulfilled, in principle, by the attribution of equal privileges and responsibilities to all.

The principle applies to every domain of human activity, profession, company, locomotion, contract, association, leisure, etc. If the statutory law demands higher education for a person to become a physician, this requirement should be extended to

42 See Infra: 10. Speech and Action. 
everyone, except for reasons that may justify different legal treatment (in this case, hard to imagine). There is no difference regarding speech. If men are equal in dignity and earn the same degree of respect, restricting only some ideas instead of others would mean that those who sustain them are less worthy.

Alexander Meiklejohn linked free speech and equality in a sounding equation: "No belief or advocacy may be denied freedom if, in the same situation, opposing beliefs and advocacies are granted freedom". Implicitly criticizing the Supreme Court's ruling in Schenck, and the persecution of the Communists after the Russian revolution and during the cold war, Meiklejohn settled his formula with these remarkable words: "If then, in any occasion in the Unites States, it is allowable to say that the Constitution is a good document, it is equally allowable, in that situation, to say that the Constitution is a bad document. If a public building may be used in which to say, in time of war, that the war is justified, then the same building may be used in which to say that it is not justified. If it be publicly argued that conscription for armed service is moral and necessary, it may be likewise publicly argued that it is immoral and unnecessary. If it may be said that American political institutions are superior to those of England or Russia or Germany, it may, with equal freedom, be said that those of England or Russia or Germany are superior to ours" 43 .

The principle of equality does not only prohibit the legislative power from denying some persons the right to profess specific ideas out of disagreement and contrariety while guaranteeing others the right to say the opposite. It binds all public powers. For the judiciary, equality takes the form of a duty to invalidate viewpoint discriminations established by statutory law and prevent people from being silenced, imprisoned and held accountable. When legislative power yield to inquisitorial pressures of majorities or influential organizations, the courts must stop the course of intolerance and guarantee the benefits of equality without distinction of ideas.

It is true that equality is not totally closed for legal differentiations. Sometimes, granting some people the rights denied to others is indispensable to compensate unfortunate situations and to balance opportunities. It might be said that it is the case when the law reserves a percentage of vacancies in public service to the disabled. Other times, the denial of rights granted to others is permissible based on the logical correlation between alegitimate objective and the factor of distinction. It is possibly the case when the law sets a minimum age for entry into the armed forces, where retirement takes place early, and youth and excellence of physical condition are requirements for doing a good job in the field for the most time possible.

43 MEIKLEJOHN, Alexander. Testimony Presented Before the Subcommittee on Constitutional Rights, United States Senate Committee on the Judiciary (1955). In: BLASI, Vincent. Ideas of the First Amendment. St. Paul: Thomson West (American Casebook Series), 2006, p. 771-772. 
Discriminating speech does not fit into either perspective. To promote equality in fact, government does not need to criminalize and suppress the thought it dislikes or diverges from. Ensuring that poor or black students have better opportunities in life does not depend on outlawing speech, but rather may be attempted through the adoption of affirmative programs such as support for the family and pregnant woman since prenatal care, breastfeeding control, free enrollment in kindergartens and school meals, permanent qualification of elementary education and, perhaps temporarily, granting scholarships and setting quotas in universities. It is not indispensable to silence and punish those who have non-egalitarians views of society.

\section{SPEECH AND ACTION}

Beyond democracy, truth, tolerance, autonomy and equality, there are at least two additional reasons for protecting speech. First, in general, speech contains lower degree of danger compared to actions (i.e., non-communicative actions, like driving or shooting), at least in the short run. So, there is no need to subject speech to the same rigid controls. Speech is the kind of human activity most compatible with full liberty. It is not by chance that most civil and criminal offenses concern to actions, not speech, as in the cases of physical assault, bank robbery, kidnapping, attempt to commit murder, speeding, drunk-driving and so on.

It is more dangerous firing a weapon toward an adversary than just announcing enmity feelings. It is more dangerous to regiment guerrillas and set fire to the government headquarters than presenting a lecture on the morality of the Marxism. Therefore, violent actions are usually more problematic than speech. Before actions, the time to react is slight, the chances of defense are reduced, brutality is often physical, material, and evils tend to be intense and, above all, immediate. Police response requires promptness and perhaps violence. There is no margin for tolerance. Criminal punishment must be strong enough to be exemplary. Here is a set of effects and demands that could hardly apply to something just said or written.

According to Edwin Baker ${ }^{44}$, the shrill voice breaking a crystal cup is an aberrant example, and also something that does not even match with the usual notion of what speech means. The sound shattering the glass is, strictly speaking, pure physical force. Surely, speech is not always inoffensive. It is an exaggeration to say that "sticks and stones can break my bones, but names will never hurt me". However, in most cases, thesis a suitable metaphor.

The lesser capacity to produce immediate and irreversible effects is not a final reason for protecting speech. Yet, it helps to justify the difference between actions and speech regarding to the respective legal treatment. Actions are significantly repressed

44 BAKER, Edwin C. Human Liberty and Freedom of Speech. New York: Oxford University Press, 1989, p. 55. 
while speech is significantly protected. Once the potential to injure is lower, punitive interventions are less needed. Tolerance is possible, and, in principle, bad ideas can be counteracted with good ideas. There is time to react through debate and instruction without resorting to relentless methods of force.

Using force to counter bad ideas is not just pointless, but also something misplaced. Bad actions often violate the rights of others. In a theft, for instance, there is a violation of property right; in a homicide, of the right to life; and in default, of the right to receive the payment in the due date. Conduct reprehensibility stems precisely from damage to the protected legal good. Exceptionally, when the action is committed by a person with a mental health condition, is imposed as a means of defense or is associated with a fortuitous event, the illicitness disappears because there is no connection between a reprehensible conduct and the injurious result.

Something different happens with speech, especially having in mind the assertive type ${ }^{45}$, that is, statements of facts and values that the speaker sincerely believes to be true or correct and intends to be taken as such by the listeners. Even when the content is shocking, asserting something never implies violation of anyone's right, but rather it means the use of one's own right to assert it. As to other kinds of speech acts, such as the directive (orders, requests, advices, etc.) and the commissive (promises, oaths, etc.), the same thing generally occurs, although not always.

Having a right is to be able to demand something from someone (an object, an action, an omission, etc.); having a right violated means that someone didn't do what was demandable. But if John thinks and says, hypothetically, that it is morally justifiable to fight the bourgeois society, or if John feels and says he hates Jews for having killed Jesus Christ, John won't be violating anyone's right simply because no one has the right to demand from him to think or to feel otherwise. His opinions and his emotions may be bad, but they do not cause an illegal harm to anybody. On the contrary: it is John's own right to express what he believes and feels. If John believes and says that only 50,000 Jews died during the holocaust or if John joins a demonstration in favor of abortion legalization, again John won't damage anyone's right because no one has the right to demand from him to believe in another version of history or to embrace another political cause. The version can be fragile and ridiculous, and the agenda may seem immoral and impious; however, they are not illicit.

Therefore, speech differ from actions because it tends to be less unsafe and not to violate rights. It is neither needed nor proper to subject both to the same inflexible canons. There is a fine-tuning between the nature of speech and the possibility of freedom. The antidote to evil thinking should not be the speaker's enforced silence or

45 On the taxonomy of speech acts, see: SEARLE, John R. Expression and meaning. New York: Cambridge University Press, 1981, p. 1-29. 
penalty, but the counter-coupling of freedom itself. As Louis Brandeis once wisely said: "the fitting remedy for evil counsels is good ones" 46 .

It must be said, on the other hand, that speech loses value when it implicates deliberate and detrimental consequences to other's man rights. That's what happens when we are before communications like the false cry of fire in a theater causing panic in the crowd, among many others sorts of wrongdoings made with words, such as an intentional false report of a crime, agreements to commit a murder, bullying, harassment, slander, threats to get sexual intercourse, encouragement of suicide, etc. Here, as earlier noted, there is more action than speech. It's in fact the case of dolng evil things to someone by saying, not of only saying something evil ${ }^{47}$, and it is expected that protect ed rights will be violated, such as the right everyone has of not being falsely reported as a criminal or terrified to make unwanted sex.

In hate speech cases, by the way, it is critical to distinguish. One thing is to state, assertively, for instance, that "life was better when blacks and whites were separated". No one has the right to demand a different view, and free speech values apply. But there are some quite different scenarios. The first is hateful incitement: when someone directly asks the listeners to take illegal, imminent and harmful actions against a person or a group based on prejudices of race, religion, origin, gender or sexual orientation. The second is hateful threat: when someone threatens to take illegal and harmful actions against a person or a group with the intent to cause fear and terror on the same basis. The third is hateful insult: when someone, mostly in a face-to-face encounter, utters racist epithets against a person with the only purpose of wounding, humiliating or provoking a fight. Again, these are cases of dolng evil thlngs to someone by saylng(inciting, threatening and humiliating or provoking a fight), not of only saylng something evil. Accordingly, rights will be certainly hurt, and free speech values are hardly reachable.

\section{CONCLUSION: AN ENLIGHTENING CASE}

Considering all things together, the common understanding is that government is forbidden to repress speech on a content basis. Content-based limitations are mainly those which prohibit and punish speech because of the supposed untruth or wrongness of the message. What generally happens in this case is that the government disbelieves what the speaker believes, that is, the government does not accept as true the proposition that the speaker takes as so.

\footnotetext{
46 Whitney v. California. Supreme Court of the Unites States. 274 U.S. 357 (1927).

47 The distinction between only saying and doing by saying in the hypotheses we are considering here has a clear connection to Austin's theory of illocutionary acts, especially with the distinction between constative and performative categories. According to Austin, the "performative-constative distinction" is "a distinction between doing and saying". See: AUSTIN, J.L. How to do things with words. 2. ed. Cambridge: Harvard University Press, 1975, p. 47.
} 
There is an enlightening case. In 1959, the US Supreme Court faced an episode regarding a forbidden film. It was Lady Chatterley's Lover, a movie adaptation of D. H. Lawrence's novel. The story is about Constance, a young woman whose husband Clifford Chatterley becomes paralyzed and sexually incapacitated. Constance lives the frustration of a conjugal relationship in which soul and body conflict. Married to an impotent aristocrat, she gets involved with an employee and commits adultery. The ardent moments of lovers' intimacy are the plot highlights.

New York State law conditioned cinematographic exhibits to prior permission of its education department. Under the original wording, the law provided that the license should not be granted if the movie, in whole or in part, was obscene, indecent, immoral, inhuman, sacrilegious or was of such a nature that its display tended to corrupt the moral or incite crime. An amendment was later added to clarify what the word immoral and the sentence tended to corrupt the moral meant. According to the amendment, a movie would be immoral and susceptible to corrupt morality when its dominant purpose or effect was erotic or pornographic; or when exposing acts of sexual immorality, perversion or lust, or when expressly or implicitly presenting such actions as desirable, acceptable or appropriate standards of behavior.

Lady Chatterley's Lover distributor submitted the tape to the responsible division. The license was denied. The movie could only be shown if three scenes considered immoral were deleted. It did not take care of mere restriction of children and teens access. It was a total prohibition even for the adult audience. There was an appeal to another administrative instance, but it was unsuccessful. Even worse: the denial was kept but on a broader basis. The problem was not the three separate scenes, but the whole movie was immoral under the law because presented adultery as desirable, acceptable, and appropriate. The case came to courts. The Court of Appeals in the State of New York was divided and reformed a lower court decision that favored the distributor and backed the administrative refusal of the license. According to the prevailing opinion, the prohibition suited the legislation purpose because the movie's matter was adultery presented as right and desirable for certain people under certain circumstances. Thus, the litigation reached the Supreme Court.

The case was decided in favor of the producers thanks to the content-based motivations behind the ban. The license was denied on the sole ground of being immoral the condescending exposure of an adulterous relationship. The reason was not that the movie incited adultery. An argument like this probably would not work in the face of the American constitutional legal doctrine at the time. In Whitney v. California, the Supreme Court had previously suggested that abstract advocacy of illegal conducts does not constitute incitement. Incitement is something like a speech intentionally intended to lead the audience to an unlawful activity that is likely to occur immediately. Lady Chatterley's Lover's ban was based only on the supposed immorality of the adultery 
justification. According to authorities, the movie presented adultery as desirable, acceptable, and appropriate for certain people under certain circumstances, and that was immoral. This is a fair illustration of content-based censorship and viewpoint discrimination. One could believe and speak bad things about adultery, but not good ones.

Justice Potter Stewart wrote the Supreme Court's opinion. He wrote initially: "What New York has done, therefore, is to prevent the exhibition of a motion picture because that picture advocates an idea - that adultery under certain circumstances may be proper behavior." He further added: "It is contended that the State's action was justified because the motion picture attractively portrays a relationship which is contrary to the moral standards, the religious precepts, and the legal code of its citizenry." Then, he concluded: "This argument misconceives what it is that the Constitution protects. Its guarantee is not confined to the expression of ideas that are conventional or shared by a majority. It protects advocacy of the opinion that adultery may sometimes be proper behavior, no less than advocacy of socialism or the single tax. And in the realm of ideas it protects expression which is eloquent no less than that which is unconvincing" ${ }^{\prime 48}$.A short ruling that corroborates the principle of neutrality: government may not censor speech just because its agents do not like or diverge from it, whether they are legislators, administrators or judges.

Potter Stewart could have argued that Lady Chatterley's Lover is a fiction work, and it does not necessarily contain a value judgment on adultery, that it is just a narrative, a description of some possible human experience. He could have questioned the conclusion that the story meant to support lovers' conduct. However, if Potter Stewart moved in that direction, he would not face the critical question under examination, whether the government is entitled to forbid an opinion just because it is contrary and discordant to the one it prefers, the only one that is deemed compatible with the desirable moral. Potter Stewart examined the case validating the assumption that Lady Chatterley's Lover did indeed contain a supportive message about adultery. Doing so, the US Supreme Court protected the opinion despite its content.

Somebody who asserts that adultery is sometimes acceptable holds a point of view, a moral opinion on human behavior. He or she states a point that may influence marriage legislation. He or she takes a side before a question that does not have a unique, and inescapable answer. He or she speaks his/her mind, maybe opening a contest that, locked in the ring of ideas, educates for civilized coexistence. Lady Chatterley's Lover's proscription infringed the right to say no matter what without fearing censorship or punishment and contradicted the cardinal values by which free speech is rightly guarded: democracy, truth, autonomy, tolerance, and equality.

48 Kingsley International Pictures Corp. v. Regents of the University of the State of New York. Supreme Court of the Unites States 360 U.S. 684 (1959). 


\section{REFERENCES}

AUSTIN, J. L. How to do things with words. 2. ed. Cambridge: Harvard University Press, 1975.

BAKER, Edwin C. Human liberty and freedom of speech. New York: Oxford University Press, 1989.

BALKIN, Jack M. Digital speech and democratic culture: a theory of freedom of expression for the information society. In: BLASI, Vincent. Ideas of the First Amendment. St. Paul: Thomson West (American Casebook Series), 2006.

BARENDT, Eric. Freedom of speech. 2. ed. New York: Oxford University Press, 2007.

BOBBIO, Norberto. A era dos direitos. 8. ed. Tradução de Carlos Nelson Coutinho. Rio de Janeiro: Campus, 1992.

BOLLINGER, Lee C. The tolerant society. New York: Oxford University Press, 1986.

CHEMERINSKY, Erwin. Constitutional law: principles and policies. New York: Aspen Publishers, 2006.

DERSHOWITZ, Alan M. Shouting fire: civil liberties in a turbulent age. Little, Brown and Company, 2002.

EMERSON, Thomas I. Toward a general theory of the First Amendment. New York: Random House, Inc., 1966.

ESPINOSA, Baruch de. Tratado político. São Paulo: Abril Cultural, 1983.

FALLON, Richard H. The dynamic constitution: an introduction to American constitutional law. Cambridge University Press, 2004.

FISS, Owen M. The irony of free speech. Cambridge: Harvard University Press, 1996.

FRIED, Charles. Saying what the law is: The Constitution in the Supreme Court. Cambridge: Harvard University Press, 2005.

GREENAWALT, Kent. Fighting words: individuals, communities, and liberties of speech. New Jersey: Princeton University Press, 1995.

GREENAWALT, Kent. Speech, crime, and the uses of language. New York: Oxford University Press, 1989.

LEWIS, Anthony. Freedom for the thought that we hate: a biography of the First Amendment. New York: Basic Books, 2007.

LOCKE, John. Carta sobre a tolerância. Lisboa: Edições 70, 1987.

MEIKLEJOHN, Alexander. Political freedom: the constitutional powers of the people. New York: Oxford University Press, 1965. 
MEIKLEJOHN, Alexander. Testimony presented before the Subcommittee on Constitutional Rights, United States Senate Committee on the Judiciary (1955). In: BLASI, Vincent. Ideas of the First Amendment. St. Paul: Thomson West (American Casebook Series), 2006.

MILL, John Stuart. On liberty. In: BLASI, Vincent. Ideas of the First Amendment. St. Paul:Thomson West (American Casebook Series), 2006.

SEARLE, John R. Expression and meaning. New York: Cambridge University Press, 1981.

SHAPIRO, Martin. Freedom of speech: the Supreme Court and judicial review. New Jersey: Prentice-Hall, Inc., 1966.

SCHAUER, Frederick. Free speech: a philosophical enquiry. In: BLASI, Vincent. Ideas of the First Amendment. St. Paul: Thomson West (American Casebook Series), 2006.

TINDER, Glenn. Tolerance and community. Columbia: University of Missouri Press, 1995. 